\title{
Bergerak di Ruang Antara ${ }^{1}$
}

\section{Irfan Palippui}

Advanced training (Nasional)/ LK III BEM UNM bisa disebut sebagai strategi pelatihan yang unik. Ia seperti suatu proses di mana irisan penamaan dan peristiwa tidak bekerja dalam satu ruang dan waktu. Kita barangkali akan menduga bahwa peristiwa pelatihan ini merupakan proses panjang, kemudian level puncak ditandai pada proses sedang berlangsung ini. Yang menganggap telah ada peristiwa panjang terjadi sebelum saat ini; telah ada pelatihan nan "rumit" , proses belajar dengan sekelumit rujukan, sehingga hanya orang terpercayalah secara "pengalaman" yang disodorkan dari organisasi mereka mengisi posisi duduk di ruangan ini. Sebuah proses di mana segala kematangan administrasi, verifikasi partisipan menjadi riwayat paling menentukan. Sebutlah ia detik-detik terakhir di mana cita-cita perjuangan serta topik dan wacana bombastik memang menjadi suatu yang sangat layak dibincang. Akan tetapi, sejauh pengalaman dan pengamatan saya pribadi, irisan itu justru berjalan sendirisendiri. Nama dan peristiwanya justru tidak terikat sebagaimana "cakar ayam" pada gedung besar yang disiapkan untuk mengantisipasi kelak retak atau robohnya bangunan tersebut. Di sinilah paradoksnya kegiatan pelatihan ini yang sekaligus membuatnya menarik. Ia menarik karena dapat menawarkan

\footnotetext{
${ }^{1}$ Tulisan ini dibawakan pada kegiatan Advanced Training Nasional XIV BEM UNM di Makassar, 17 -01-2018.
} 
kemungkinan lain dari suatu model ajek yang justru selama ini mengurung penglihatan mata kita. Bahkan bisa melahirkan bentuk kebebasan baru, jika saja modus training ini mampu melampaui bentuk-bentuk ajek itu sendiri. Di sanalah “ ruang antara" akan kita bahas lebih jauh nanti.

Satu hal paling membanggakan dimiliki sebagian besar mahasisiwa Makassar adalah militansinya. Militansi ini kadang diartikan keberanian mereka "melawan maut" sekalipun ketika memperjuangkan sesuatu. Mereka berani mempertaruhkan apapun saat merasa harga dirinya direnggut; ketika ketidakadilan sedang mempermainkannya. Pada titik ini kategori tersebut menjadi napas penting, dan terbukti telah ditunjukkan dari sekian banyak protes yang selalu diakhiri dengan perlawanan yang menggetarkan. Ini menunjukkan bahwa gerakan mahasiswa Makassar memiliki suatu kekuatan yang telah menubuh dalam dirinya, yang tentunya bisa dioperasikan dalam segala aspek hidup. Inilah energi yang bisa dipinjam sebagai dramaturgi gerakan. Dramaturgi yang dipakai menciptakan performa gerakan di mana kata militansi menjadi perwujudan emansipasi dan rasa setara sejak dalam pikiran. Di sinilah istilah mendifinisakan ulang gerakan mahasiswa menemukan tempat. Dengan kata lain, kita sedang memerlukan dramaturgi baru dalam situasi dan konteks masa sekarang dalam menempatkan mode gerakan, sehingga manifestasi energi di atas mendapat tempat lebih luas. Kita memerlukan dramaturgi gerakan baru untuk menunjukkan menubuhnya militansi sebagai emansipasi dan rasa setara sejak awal mula. 


\section{Estetika Kampus (Pendidikan)}

Saya tidak akan berbicara banyak mengenai situasi masa lalu dan terkini dari kampus. Yang jelas saat ini, tidak banyak hal bisa diharapkan dari regulasi yang dipraktikkan kampus, apalagi berharap bahwa akan bermunculan banyak akademisi yang mau jujur dengan situasinya sendiri. Atau, berharap dari kelompok ini mau mengimplementasikan tesis ke sebelas Marx. Kebanyakan hanya sibuk megurusi karier, jabatan akademik, pendanaan penelitian dengan dalih pengabdian kepada masyarakat. Bahkan di antaranya memilih menjadi intelektual impostor, native informan, yang justru menggadaikan pengetahuan lokal untuk keperluan data bagi negara-negara imperialis. Kampus tidak ada bedanya dengan pasar di mana brand lebih subtansi ketimbang keinginan mendorong perubahan atau menjadi sumbu kebebasan berpikir. Mahasiswa hanya dijadikan konsumen pasif untuk meraut keuntungan banyak. Merekalah komoditas utama dari regulasi itu sendiri, yang terus diselubungi oleh janji masa depan, iming-iming mengubah nasib dengan pengetahuan dan skill yang diraihnya setelah melewati segala aturan mainnya.

Apa yang ditunjukkan oleh kampus pada intinya persis dengan logika demokrasi yang dipraktikkan negara. Alih-alih bermulut demokratis tetapi faktanya adalah aristokrasi - kekuasaan yang hanya dimiliki oleh sekelompok atau segelintir orang saja. Demikianlah mahasiswa sebagai civitas akademika, yang secara tertulis adalah bagian, tetapi hak-haknya selalu diukur dan dibatasi. 
Mereka dikurung dalam ruang dan waktu simbolik, kapan dan bagaimana harusnya berbicara (mengutarakan keinginannya). Mereka disekap dalam sistem distribusi rasa-nalar (sensible distribution) atas mereka yang dianggap paling berhak mengatur dan mahasiswa diatur. Inilah sistem distribusi yang membekukan persepsi atas apa yang mungkin dilihat, dan disuarakan. Mahasiswa tidak menjadi bagian untuk melihat sesuatu yang semestinya juga bagiannya. Mereka berada pada posisi di mana yang tampak saja boleh dicerap dan tidak untuk yang tak tampak. Mereka berada pada apa yang boleh disuarakan dan tidak boleh disuarakan. Di sinilah ia untuk kali pertama tidak memiliki kebebasan atas dirinya, hak setara mendengar, memahami, dan menyuarakan sesuatu. Ia kemudian menjadi bagian yang bukan bagian dan telah tercacah dalam sebentuk takdir, yang mempartisi dan menempatkan aktivitasnya dalam ruang dan waktu yang telah ditentukan oleh rezim distribusi (Rancière, 2004: 12). Singkatnya, kita tahu bahwa kampus bakal tidak ada ada tanpa mahasiswa, tetapi kita terus digoda untuk membuatnya terus ada. Kita tahu bahwa syarat mutlak sebuah kampus adalah mahasiswa, namun ia sengaja dipasifkan dengan dalih bahwa mereka adalah "gelas kosong" yang siap untuk diisi oleh orang-orang jenius.

Masalah gelas kosong atau mahasiswa pasif adalah model distribusi yang tak hentinya digaungkan kampus demi mempertahankan dominasinya, untuk terus menjaga pasarnya. Di samping, metode pengajaran serta desain kurikulum terus menerus memperpanjang hirarki kesesatan di atas. Di kelas, sistem pembelajaran selamanya memperlakukan mahasiswa sebagai “domba-domba” yang harus diberi 
penjelasan untuk memahami materi-materi pembelajaran. Padahal apa yang dibaca sang pengajar belum tentu sama persis dengan apa yang dimaksudkan buku-buku yang sedang dipelajari. Artinya, sang pengajar juga hanya mengemukakan tafsirannya atas bacaannya, di mana juga hal itu mungkin dilakukan oleh mahasiswa. Di sinilah staltifikasi pembelajaan tidak menemukan ujung pangkal, untuk mengatakan bahwa sistem distribusi atas pencacahan pada apa yang tampak dan tidak tampak terus terpelihara. Mahasiswa kemudian menjadi pelanjut staltifikasi kelak menjadi pengajar dan melakukan hal yang sama. Apa yang terjadi dalam ruang kelas merupakan praktik yang tidak ekual sedari awal, sehingga upaya membebaskan diri dari cengkraman atas ketetapan takdir dari kekuasaan kian ringkih. Pada titik inilah estetika kampus atau pendidikan sebagai estetika mendapat ruang sebagai dasar mengoreksi sekaligus menerabas palang staltifikasi ini.

Sampai di sini, estetika tidak cukup diterjemahkan sebagai keindahan yang dipakai kebanyakan orang menjelaskan karya seni. Atau estetika tidak cukup dipahami sebagai gerakan politik dengan media karya seni. Kalau kita mengingat apa yang dianalogikan Foucault via sense Kantian kita akan mengerti bahwa inti estetika terletak pada rasa - sebuah pengalaman merasakan (rasa) yang bentukbentuknya hadir melalui sistem aprioris. Atau tangkapan spontan/sekilas dari sesuatu di mana kata-kata sama sekali tidak dapat mengatasinya. Pengalaman rasa inilah memberi kemungkinan untuk mengeliminasi ruang dan waktu, yang tampak dan tidak tampak, yang secara simultan menempatkan bentuk-bentuk pengalaman 
sebagai gerakan atau tindakan politik. Meski "politik" di sini bukan pula politik sebagaimana ia dipahami seperti police yang senang memperebutkan kekuasaan, baik dalam pemilu atau pilkada yang banyak ditonton belakangan ini. Bentuk pengalaman rasa atau kita sebut pengalaman estetika inilah kemudian menyingkap apa yang selama ini tak tampak sehingga membuatnya memiliki kemampuan melihat dan menyuarakan apa yang dirasakan dalam ruang dan waktu subjek selama ini. Pengalaman estetika mampu melahirkan subjek politik yang bukan lagi bertujuan mengambil bagian dari rezim distribusi, tetapi menempatkan dirinya secara ekuel dalam ruang dan waktu itu sendiri.

Ketika membaca gagasan estetika Schiller kita menemukan bagaimana estetika mampu melampaui batas-batas distribusi tersebut. Lewat play drive-nya kita bisa memahami bagaimana rasa dan rasio mampu terbebas dari tekanan jika hal tersebut terintegrasi. ${ }^{2}$ Di titik ini Schiller bukan pada posisi bicara filsafat, tetapi mulai menerabas jalan buntu filsafat membicarakan estetika. Filsafat selalu mendudukkan estetika berhadapan dengan Reason, kemudian Schiller membawanya pada kepekaan rasa atau sense itu sendiri (Pilling Diana// Springer, 2008: 1-2). Play drive merupakan inti kebebasan, sekaligus keluar dari aturan

\footnotetext{
${ }^{2}$ Schiller memperkenalkan apa yang disebutnya play drive yang diambil dari Kant (free play of the powers of representation) dan ide Fichte mengenai drive (triebe). Kedua konsep ini mengutarakan bahwa pengalaman manusia sangat tergantung pada sensous drive dalam diri setiap orang dan formal impulse (form tribe) yang berfungsi membawa harmoni pada pengalaman. Jika keduanya teratasi (terintegrasi) maka baik yang diindrai (sensous) maupun yang rasional dapat terbebas dari tekanan. Schiller menggunakan play drive untuk mengatasi estetika Kantian saat berhadapan dengan beauty, sekaligus menempatkan free play sebagai acuan utamanya membicarakan estetika. Perbedan awal antara Kant dan Schiller terletak pada cara ia menempatkan free Play dalam seni bukan dalam rangka mengungkap kebenaran.
} 
moral akal-budi yang didudukkan oleh Kant sebagai kategori dalam mencapai kebebasan. Bagi Schiller, moral akal-budi tidak cukup membawa seseorang untuk sampai agape - cinta. Yang bisa membawa manusia pada cinta (cinta diartikan ketika kedua drive bermain) adalah ketika rasa (sensous) dan rasio (formal drive) bekerja sekaligus. Inilah diistilahkan Schiller dalam Letters Upon The Aesthetic Education of Man, bahwa manusia hanya akan menjadi manusia ketika bermain (Wertz, 2005: 94; Ranciere, 2010: 115). Tanggapan ini sekaligus mengeritik jalan Kant mengonsepsikan moralitas masyarakat dalam hukum an sich di mana maksim a priori (formal) menjadi penentu hukum universal. Artinya, maksim empiris (material) yang mengacu pada hasrat indrawi sebagai hasil tindakan bukan projek yang dapat menghasilkan universalisme subjektif (Hardiman, 2007: 146-147). Sehingga, pengalaman rasa melalui ruang dan waktu yang tercacahcacah itu, memungkinkan lahirnya subjek politik. Subjek yang tahu cara menyatakan dan menyuarakan diri dan lingkungannya sendiri. Inilah "ruang antara" di mana subjek bermain-main, yang memainkan dirinya menjalani kebebasanya.

\section{Berpikir lewat Puisi/Teater}

Hanya dengan bermain "di ruang antara" kebebasan menjadi manusia dapat diraih. Sebagaimana optimisme Schiller pada permainan itu sendiri, ia memberikan harapan bahwa pada titik ini, seni menjanjikan kebebasan pada kehidupan manusia. Dengan kata lain cara seni memberikan jalan dalam 
mencipta dramaturgi baru gerakan mahasiswa. Sebagaimana tawaran Schiller, dengan melokasikan beauty dari form practical reason ala Kant (bahwa sesuatu ada pada dirinya sendiri) ia kemudian menulis "The ground of beauty is everywhere freedom in the appearance. The ground of our representation of beauty is technique in freedom" (Wertz, 2005:83-85; Schiller, 1910:2). Teknik itulah diartikan kemampuan seniman menciptakan objek keindahan - meski tidak semata-mata bertumpu pada teknik - di mana di dalam objek telah terisi kebebasan (inner freedom atau gracefulness). Dari sini pula, karya seni dilihat Schiller menjadi sejatinya politik pembebasan. Untuk dapat mengatasi masalah politik, kata Schiller, satu-satunya jalan adalah seseorang mesti mengambil jalan estetika, sebab ia adalah kebebasan itu sendiri. Seni memberi harapan sebab ia adalah anak kandung dari kebebasan; ia membebaskan manusia dengan semangat dan energinya keluar dari tekanan kebutuhan material, misalnya. Di sinilah ia menjadi politis dalam arti tidak bertujuan mendorong orang meninggalkan panggung politik, lalu masuk menikmati panggung teater. Poinnya, seni mendorong manusia mengalami kebebasan agar berani meninggikan diri sesuai keinginanya (Wertz, 2005: 85; Schiller, 1910: 3). Lalu, bagaimana estetika menjadi peristiwa politik yang membebaskan?

Pada potongan pengantar di atas telah mula-mula saya nyatakan adanya keunikan dalam forum training ini. Tentang adanya irisan "tidak nyambung" antara nama dan peristiwa sehingga hal itu memungkinkan kita menerabas dan menemukan jalan lain. Suatu momen di mana ruang dan waktu terputus, yang 
dirasakan atau disadari kejadiannya, tetapi kita terus melakukannya. Ia seperti film (atau paling parahnya sinetron) yang kita tahu bahwa itu adalah rekaan namun tetapi ngotot mengalaminya sebagai kenyataan/kebenaran. Begitulah peristiwa keseharian itu bekerja, yang bukan saja dialami oleh sedikit untuk tidak mengatakannya pada setiap orang. Itulah wujud nyata untuk melihat bagaimana sebuah ideologi beroperasi, di mana sesuatu dialami secara sadar tetapi masih saja dilakukan, dan bukan karena ketidaktahuan. Pada titik ini kita akan menyatakan bahwa segalanya tergantung pada fantasi yang menopang dan menstruktur kenyataan sosial pada dirinya. Fantasi itulah menopang segala laku dalam ruang dan waktu simbolik. Sehingga, jika kita mau mengakses fantasi orang lain, catatlah apa yang mereka lakukan. Di sinilah ideologi itu bersarang kata Zizek, jangan lihat seseorang dari apa yang dipikirkannya, tetapi lihatlah pada apa yang dilakukannya (Lechte, 2015: 192). Jadi, ilusi ideologi hadir dalam laku keseharian, di mana seseorang menjalaninya dengan meyakini, misalnya gambargambar dalam tv, sesolah-olah memiliki kualitas kenyataan dan kebenaran.

Nukilan "tidak nyambung” ini mengantarai kita secara perlahan mengakui bahwa apa yang kita lakukan dalam keseharian rupanya tidak lebih dari laku rekaan/fiksi. Kehidupan adalah sebuah fiksi besar yang ditata sedemikian rupa oleh akal (Reason) kemudian mengatakannya sebagai fakta. Meski kenyataan sehari-hari kita selalu mengelak dari apa yang dikatakan Lacan, bahwa ketidaksadaran terstruktur seperti bahasa (Dor dan Gurewich, 1998: 45). Struktur bahasa yang kita pakai tak lain adalah penanda (metaphor/metonomi) yang selalu 
diselubungi oleh yang tak sadar (alam bawah sadar). Irisan “ tidak nyambung” ini memang tampak begitu paradox. Di satu sisi, operasi penanda bahasa ini juga dioperasikan oleh kapitalisme untuk menseduksi subjek menjadi fetis. Namun, operasi penanda (metafora/metonimi) dalam produksi karya fiksi (seni-sastra) sekaligus bisa mendorong sublimasi (atau mengubah tatanan) atas dominasi yang opresif. Di sinilah puisi/teater (atau seni lainnya) melampaui segala macam gerakan baik menyebut dirinya progresif dan sejenisnya. Sebelum sampai pada seni dapat melampaui atau menciptakan sublimasi, saya akan menunjukkan jauh sebelum omongan ini bagaimana sikap Plato terhadap puisi/teater atau seni lainnya.

Dari sekian banyak kesenian di masa Yunani Klasik, Plato begitu mewanti-wanti bahaya laten puisi dan teater. Dua kategori ini dianggap memiliki potensi lebih berbahaya daripada lukisan. Puisi merepresentasikan apa yang dilakukan manusia sehingga dapat dipercaya sebagai hasil dari tindakan kebaikan dan keburukan manusia. Puisi bisa menjadi alat propaganda, sebagaimana teater mempertunjukkan adegan mengenai kehidupan yang bisa memancing emosi dan perasaan penonton. Puisi menghadirkan kepada pembaca inner live yang mengakibatkan reaksi terhadap pembacanya. Ia bisa menimbulkan hasrat dan menunjukkan jalan bagaimana harusnya manusia hidup. Puisi memiliki kekuatan yang dapat menghancurkan masyarakat dan menjauhkannya dari kebenaran. Meskipun demikian, puisi memiliki faedah selama ia digunakan untuk kepentingan negara atau kemaslahatan umat (Plato, 2015: 454) - yang lahir dari 
tangan seorang filsuf. Dan, puisi tidak terlarang selama ia digunakan untuk memuji kebesaran Tuhan dan untuk kebajikan manusia (Giovannelli, 2012: 16) . Konsekuensi atas aksioma seni Plato, akhirnya, menempatkan seni (seni meniru tiruan) tersebut pada batas-batas etis - hanya bisa merujuk pada ide form kebenaran. Kalau hal tersebut tidak dilakukan, seni imitasi tersebut pantas disingkirkan dari kehidupan bernegara. Di rezim ini seni tidak eksis, sebab hanya filsuf yang memiliki kewenangan mendistribusikan kebenaran (Wertz, 2005). Bagi Plato, ada hubungan etis ketika seni melahirkan wacana ataupun praktik, sehingga harus diproteksi terjadinya desakralisasi terhadap tatanan jiwa dan tatanan sebuah polis.

\section{Mencipta "ruang antara"}

Estetika sebagai dramaturgi baru gerakan mahasiswa bisa disebut peristiwa sublimasi gerakan kampus. Disebut sublimasi yang melahirkan peristiwa karena kampus adalah estetika itu sendiri. Kampus sebagai sense, yang menemukan kembali dirinya sebagai basis gerakan perubahan, pergulatan ide-ide, dan tempat di mana kebebasan berpikir mula-mula ditancapkan. Estetika kampus inilah kemudian mengonfigurasikan rasa-nalar baru dalam ruang dan waktu subjek melakoni kesehariannya. Di sini, kita berada di antara seni dan bukan seni, di antara fakta dan fiksi. Sebagaimana dalam rezim estetik, kata Ranciere, keterhubungan seni dan kehidupan tidak hanya berada dalam bentuk, sekaligus tidak memiliki kaitan sama sekali dengan bentuk. Keterhubungan itu hanya 
muncul melalui logika dan, untuk menyatakan bahwa dramaturgi baru gerakan mahasiswa dalam domain rezim estetik terletak pada otonomi dan heterenomi. Logika dan menandakan otonomi seni tidak pada karya, tetapi mode pengalamannya. Demikian pula heterogenitas pengalaman estetik seseorang, ia juga sekaligus menggagalkan keotonomian tersebut. Pengalaman dalam logika dan (dalam hal otonomi dan heteronomi) menjadi pengalaman estetik sejauh ia sekaligus bukan seni (insofar as it is not, or at least not only, art) (Ranciere, 2010: 116-117).

Lewat pendekatan estetika kampus sebagai dramaturgi gerakan kita tidak lagi berbicara subjek dan objek, namun kesetaraan menjadi landasan pemberangkatan yang mengeliminasi dominasi sedari awal. Kesetaraan yang dimaksud bukan lagi pada wilayah yang mengetahui dan tidak mengetahui, dosen dan mahasiwa, laki-laki dan perempuan, akan tetapi bagaimana memperlakukannya tidak lagi sebagaimana membaca kondisi sosiologis (Pelletier, 2009: 8), seperti kondisi menjadi perempuan di hadapan patriarki. Sebab hal itu hanya akan mengembalikannya pada situasi tidak setara, sementara yang dilakukan adalah produksi wacana di mana kesetaraan harus telah terjadi sejak awal mula. Kesetaraan merupakan hasil emansipasi, yang nantinya diharapkan memberi kemungkinan-kemungkinan baru.

Secara implisit emansipasi dapat diartikan bahwa objek emansipasi adalah orang dibebaskan menjadi independen dan kebebasan itu sendiri merupakan 
akibat tindakan emansipasi. ${ }^{3}$ Isyarat ini menunjukkan bahwa logika emansipasi berada pada dua poros hubungan, yakni emansipator dan yang di-emancipated. Di sini, terjadi pertukaran yang tidak sekadar dipahami sebagai tindakan kebebasan yang telah dilakukan kepada orang lain, tetapi motivasi utamanya pada adanya ketidaksetaraan antara emancipator dan yang di-emancipated (Biesta, 2010: 44). Olehnya itu, untuk memasuki medan kesetaraan atau menciptakannya diperlukan campur tangan atau intervensi dari emancipator. Inilah kemudian menjadi paradox, yang memunculkan pertanyaan tentang posisi atau akibat ketergantungan itu sendiri. Dalam arti, kita membayangkan emansipasi lewat kesetaraan namun di sisi lain dibayangi oleh intervensi. Lantas bagaimana menempatkan ketiganya? Bagaimana menempatkan intervensi tersebut dalam dramaturgi gerakan ini? Baik, saya akan kembali menggunakan pertunjukan teater sebagai cara tatap.

Karena setiap orang berpikir, maka setiap orang setara. Kata Ranciere, dalam pertunjukan teater, emansipasi bermula disaat kita menantang oposisi antara viewing dan acting (Ranciere, 2009b: 13), antara yang pasif dan aktif (Cachopo, 2013: 1-2); dan memahami bahwa sarang dominasi dan subjeksi terjadi dalam struktur penghubung antara yang mengatakan, melihat dan melakukan. Menentang oposisi ini sama artinya menghapus bineritas antara yang aktif dan pasif, yang tahu dan tidak tahu. Ranciere mengatakan bahwa penonton juga

\footnotetext{
${ }^{3}$ Konsep emansipasi diturunkan dari hukum Romawi mengenai kebebasan istri dan anak-anak dari jeratan keluarga - khususnya, kekuasan mutlak sang ayah - sehingga kepemilikian tentang sesuatu diserahkan padanya atau mendapatkan otoritas dari orang lain untuk dirinya (Biesta, 2010: 41).
} 
akting, sebagaimana siswa atau pelajar mengobservasi, memilih, membandingkan dan menginterpretasikan konten pembelajaran. Begitulah penonton melihat panggung pertunjukan sebagaimana mereka menghubungkannya dengan tempat lainnya; ia menyusun puisinya yang didasarkan dari pembacaan puisi sebelumnya (Ranciere, 2009b: 13). Artinya, setiap penonton sudah merupakan aktor dari ceritanya sendiri dan bahwa aktor tersebut juga adalah penonton dari cerita yang sama. Oleh karena itu kita perlu menyadari bahwa peristiwa menonton bukanlah semata membawa penonton dari diri yang pasif ke diri yang aktif. Peristiwa kepenontonan merupakan peristiwa belajar sekaligus mengajar secara bersama, di mana keduanya menggunakan pengalaman masing-masing sebagai tenunan menyambungkan apa yang dilihat dengan apa yang sebelumnya telah dilihat.

Dengan demikian, hubungan antara mereka yang menyebut diri sebagai aktivis/seniman, baik ketika sedang membangun gerakan atau pertunjukan teater (misalnya), pertama-tama mereka telah memutus keinginan/ untuk menjelaskan dan memahamkan sesuatu kepada mahasiswa/masyarakat/penonton. Memutus berarti menghapus gap dari dua bentuk mengetahui, yakni: aktivis/mahasiswa/mayarakat, atau penulis/pembaca. Sebagaimana Jacotot dalam Ignorant Schoolmaster, bahwa akhir dari verifikasi ketidaksetaraan adalah proses staltifikasi (oposisi emansipasi) yang butuh intervensi (Lewis, 2012: 40). Intervensi sebagai keingininan menghapus jarak antara yang tahu/tidak tahu, aktif dan pasif - yang juga bukan berarti mewujudkan segala bentuk kesetaraan pengetahuan - tetapi mengahapus gap dari keduanya. Akhirnya, logika oposisi 
antara aktivis/mahasiwa (masyarakat) retas, sebagaimana retasanya hubungan antara mengetahui dan tidak tahu apa-apa atau penonton aktif dan pasif dalam pertunjukan. Estetika sebagai gerakan tidak sedang beraksi sebagaimana guru yang belum meng-ignorance dirinya (menghapus gap di atas), menjelaskan dan berusaha memahamkan pembaca (Heimans, 2016: 8) atau memahamkan kepada mahasiwa/masyarakat tentang sesuatu. Sebaliknya, (mahasiswa/masyarakat) pembaca laiknya penonton menerjemahkan (Bowman dan Stamp, 2011: 176) ruang antara/spektakel atau ruang ketiga (third thing) dalam istilah Ranciere (Cachopo, 2013:5), berdasarkan pengalamannya masing-masing. Dengan pola ini rekonfigurasi rasa-nalar terevokasi atas tafsir atau terjemahan diri mereka sendiri melalui ruang antara (third thing).

Terhapusnya dikotomi penonton/ yang ditonton, aktif/pasif, sekaligus menghapus dikotomi Aktivis dan mahasiswa - kita sama-sama aktivis dan mahasiswa berdasarkan pengalaman masing-masing. Ruang antara kemudian menghidupkan antara perjuangan gerakan dan hasil terjemahan masing-masing. Pendek kata, ruang antara adalah ruang yang tidak dimiliki siapa pun, tetapi hidup di antara mereka, sebentuk persekutuan tanpa mediasi yang mengafirmasikan esensi komunitarian (Bowman dan Stamp, 2011: 177). Ibaratnya hutan dan segala jenis pohon serta benda-benda lainnya, di mana seorang guru membawa muridnya menjelajahinya, guru tidak menjelaskan segala isinya dan berharap muridnya mengetahui yang diketahuinya. Ia sekadar bertanya apa dilihatnya dan apa dipikirannya, begitu seterusnya. Artinya, agar mencegah staltifikasi dalam 
menciptakan dramaturgi gerakan baru ini diperlukan "ruang antara" yang memisahkan keduanya, sehingga prinsip ekualitas mengetahui menuju emansipasi subjek terjaga. Aktivasi "ruang antara" merupakan upaya menghadirkan mahasiswa/masyarakat menjadi penggerak dalam mengartikulasikan atau menuliskan pengalamannya - menerjemahkan dan menarasikan merekonfigurasi dan meredistribusi rasa nalar. Akhirnya, ruang antara sebagai intervensi adalah mendorong subjek bicara dan mengartikulasikan apa yang tak terpikirkan dan tak terduga dari yang tidak tampak dan tidak direken selama ini.

Selanjutnya, sebelum penutup, bagian ini akan mengantarkan kita pada lapangan pertarungan, di mana film Europe 51 yang dipakai Ranciere memperlihatkan peristiwa kesetaraan dan mendorong emansipasi dengan bukan penjelasan untuk memahami, sebagai salah satu contoh titik berangkat. Film ini adalah tentang peristiwa, perjumpaan, dan kenangan (Rancière, 2003:108) tentang suatu di luar sana yang selalu absen.

Film ini diperankan oleh Ingrid Bergman, karya seorang Italian, Roberto Rossellini. Dalam cerita digambarkan seorang Irene (Ingrid) tinggal bersama suami dan anaknya. Keseharian Irene berlangsung dalam kemewahan, meski begitu anak lelakinya selalu murung dan merasa kesepian. Setiap kali ingin mengatakan keinginanya, ibunya selalu sibuk sehingga urung ia disampaikan. Akhirnya, tibalah pada peristiwa mengenaskan. Di saat Irene sedang menjamu teman-teman istimewanya, sang anak malah kembali ke kamar (setelah berjumpa 
dengan tamu ibunya) menjawab kemurungan dan keinginan yang sejak lama tak terkatakan. Sang anak melompat dari lantai atas kamarnya, dan mengakhiri hidupnya. Meski masih bisa dibawa ke rumah sakit, tetapi nyawanya tidak tertolong. Sebelum meninggal ia sempat membisik ibunya, tapi ibunya tak tahu yang dikatakannya.

“Something is happening'” kata Ranciere (Mercieca, 2012: 411; Rancière, 2003: 109). Di detik terakhir hidupnya, sang anak, mengulangi sesuatu - yang tidak diketahui dan dipahami ibunya - yang justru akan mengubah segalanya. Apa yang dikatakan anaknya di rumah sakit sebelum meninggal? Inilah misteri katakata yang akan memberangkatkan Irene pada petualangannya. Ia kemudian menjumpai sepupunya, Andrea (seorang jurnalis komunis), nama yang sempat didengar sekilas keluar dari mulut anaknya saat di rumah sakit. Andrea, kata Ranciere, " knows the reasons of this pain and he knows that it will not be cured by words" (Mercieca, 2012: 411-412; Rancière, 2003:112). Kemudian, Andrea mengusulkan kepadanya mendatangi dan melihat pemulihan penderitaan seorang ibu untuk belajar penderitaan dari orang lain.

Petualangan menuju lapangan segera bermula, dalam arti perjalanan Irene kita pakai melihat kemungkinan operasi gagasan ini. Kata Ranciere, ini adalah petualangan tanpa guide, tapi memiliki program (Rancière, 2003: 115-116). Program berikutnya, Irene kembali tanpa guide, bukan lagi pada tempat yang akan mencerahkan jiwanya, tetapi twisting of a body called by unknown (Rancière, 
2003: 116). Film ini menunjukkan bagaimana respon rasa nalar terhadap pantulan dari tatapan Irene atas apa yang dilihat sebelumnya, kemudian membalikkan tubuhnya untuk mempertanyakam kebenarannya.

Andrea hanyalah pengantara mengantarkan Irene terhubung kepada peristiwa; berjumpa dengan orang-orang; berjumpa dengan anak kecil yang sakit di mana tidak ada kata bisa menolongnya, tidak ada dokter karena absennya uang untuk pengobatan. Program Irene tercapai dengan bertemu dengan orang-orang yang sakit dan membantunya secara finansial. Di sini, Andrea menjadi metode. Ia mengajarkan kita memasuki dan menemukan sebuah kendaraan petualangan. Andrea telah mempertemukan Irene dengan banyak orang, dan untuk fase ini, pengantara (Andrea) cukup sampai di sini. Andrea (pengantara) telah mampu menjadi guru bagi Irene, dengan mengantarai apa yang berada dibalik kata-kata (teka-teki dari bisikan sang anak) dan memperlihatkan sisi-sisi yang tersembunyi dalam masyarakat. Andrea menyatukan dua sisi, yakni: Irene dan masyarakat, sebagai edukasi penyembuhan (Rancière, 2003: 114).

Menuju lapangan tanpa guide, meski memiliki program membawa Irene memasuki lapangan yang tidak diketahuinya. Di sini, Andrea tidak lagi hadir. Irene telah menciptakan ruang berdasarkan perjumpaan dengan orang-orang sebelumnya. Ia kembali, twisting body dan kali ini menjadi visitor asing, merasakan disorientasi dalam dirinya. Pada tahap ini, Irene melampaui penglihatannya sebelumnya, kemudian terhubung dengan sisi lain dari tatapan 
sekilas (glance) untuk menghubungkan antara word dan image (Lewis dalam Mercieca, 2012: 412) . Momen ini menjadi momem di mana kita diserang oleh tatapan kita sendiri. Sebagaiaman kata Ranciere, politik teater justru terletak pada connects the unconnected melalui pertunjukan (Lewis, 2012: 42), sehingga tidak ada jalan kompas bagi penonton terhadap panggung untuk dipakai memahami dunia, tetapi pantulan gaze atau glance itu sendirilah yang memungkinkan kepada setiap gerakan untuk melakukan twisting dan menemukan sisi lain.

Lewat gerakan ini, glance yang mengasingkan itu kita didesak menemukan banyak kemungkinan lain dari apa yang selama ini tampak dan tidak tampak. Tahap yang menjadikan kita sebagai foreigner (tidak tahu apa-apa) akan berupaya menemukan wilayah baru melalui glance, pantulan sekilas. Dengan meng-ignorance diri, kita sedang menunda menerjemahkan kenyataan yang sedang ditampakkan oleh rasa-nalar sebelumnya, sembari menanti kemungkinan lain yang disediakan lewat glance. Glance menyebabkan twisting body yang selanjutkan membawa dissensus (Heimans, 2016: 10), menjadi data rasa nalar baru yang membuka ruang dan dunia baru. Meng-ignorance diri berarti kita menciptakan jarak dari sensibel (yang tampak) untuk memahamkan dan menjelaskan data tatapan, sehingga dengan twisting membuka kemungkinan menemukan data lain dalam menyingkap apa tidak tampak dari keseharian selama ini. Ini adalah bentuk petualangan "politik" dari dramaturgi gerakan baru yang menyatakan "selamat tinggal" (Lewis, 2012: 4) terhadap distribusi rasa-nalar sebelumnya. Yang selama ini mengikat kita lewat partisi takdir, identitas, dan 
peran-peran dalam masyarakat. Kata "selamat tinggal" merupakan rekonfigurasi atas rasa baru, suara baru, yang tidak lagi terhubung dengan kordinat kekuasaan. Momen inilah diharapkan membuka suara-suara perjuangan lewat rekonfigurasi ruang dan waktu di mana mahasiwa percaya diri menyatakan: Kamilah Mahasiswa!

\section{Rujukan:}

Biesta, G. (2010) “A New Logic of Emancipation: The Methodology of Jacques Ranciere," Educational Theory, 60(1), hal. 39-59. doi: 10.1111/j.17415446.2009.00345.x.

Bowman, P. dan Stamp, R. (2011) Reading Rancière. Diedit oleh R. Bowman, Paul and Stamp. London \& New York: Continuum International Publishing Group.

Cachopo, J. P. (2013) "How does the spectator act? Benjamin and Rancière on the task of the spectator-translator," in. Krakow: 19th International Congree of Aesthetics, hal. 1-12. Tersedia pada:

http://artecriticapolitica.weebly.com/uploads/2/7/0/6/27060547/how_does_ the_spectator_act_proceedings.pdf.

Dor, J. dan Gurewich, J. F. (1998) Introduction to the reading of Lacan: the unconscious structured like a language. New York: Other Press. 
Hardiman, F. B. (2007) Filsafat Modern dari Machiavelli sampai Nietzsche. Jakarta.

Heimans, S. (2016) "Fieldwork in philosophy, emancipation and researcher disposition A post-qualitative research exemplar Stephen," Qualitative Research Journa, 16(1), hal. 2-12. doi: 10.1108/JHOM-09-2016-0165.

Lechte, J. (2015) “Slavoj Zizek, The Sublime Object of Ideology (Verso, 1989); Looking Awry: An Introduction to Jacques Lacan Through Popular Culture (MIT Press, 1991)," Bibliothekssystem der Universitaet Giessen, hal. 191-196.

Lewis, T. E. (2012) The Aesthetics of Education: Theatre, Curiosity, and Politics in the Work of Jacques Ranciere and Paulo Freire [electronic resource], Continuum. London \& New York: Continuum International Publishing Group.

Mercieca, D. P. (2012) “Initiating 'The Methodology of Jacques Rancière': How Does it All Start?," Studies in Philosophy and Education, 31(4), hal. 407417. doi: 10.1007/s11217-012-9297-4.

Pelletier, C. (2009) "Rancière and the poetics of the social sciences," International Journal of Research and Method in Education, 32(3: European Philosophy and Theory: Some New Bearings in Educational Research Methodology), hal. 19. doi: 
https://doi.org/10.1080/17437270903259741.

Pilling Diana// Springer, M. C. (2008) Friedrich Schiller, Ilo. Tersedia pada: http://www2.hawaii.edu/ freeman/courses/phil330/12. SCHILLER.pdf.

Ranciere, J. (2009) The Emancipated Spectator. London \& New York: Verso.

Ranciere, J. (2010) Dissensus on Politics and Aesthetics. Diedit oleh S. Corcoran. London \& New York: Continuum International Publishing Group. doi: 10.1007/s13398-014-0173-7.2.

Rancière, J. (2003) "Short Voyages to the Land of the People." California: Stanford University Press, hal. 141 p. Tersedia pada: http://books.google.com/books?hl=en\&lr=\&id=AQEIo_9_8iAC\&oi=fnd\& pg=PA1\&dq=Short+voyages + to + the + land + of + the + people $\&$ ots $=$ VNXi4B yoP-\&sig=K2JgimzzUf1iPVSdTLMxaea8s_Y.

Rancière, J. (2004) The Politics of Aesthetics, The Distribution of the Sensible. London \& New York: Continuum International Publishing Group.

Tanke, J. J. (2011) Jacques Rancière : An Introduction. London \& New York: Continuum International Publishing Group. doi: 10.5040/9781472546968.

Wertz, W. F. (2005) “A Reader's Guide to Letters on the Aesthetical Schiller's Education of Man,” Fidelio, 14(1-2), hal. 80-104. 
